\title{
Identifying Environment Aspect in Academic Enhancement Support for Student-Athlete Using Fuzzy Delphi Method
}

\author{
Mohd Zulfadli Rozali ${ }^{1 *}$, Saifullizam Puteh $^{1}$, Faizal Amin Nur Yunus ${ }^{1}$, Thariq Khan Azizuddin \\ $\mathrm{Khan}^{2}$ \\ ${ }^{1}$ Faculty of Technical and Vocational Education \\ University Tun Hussein Onn Malaysia, Batu Pahat, 86400, MALAYSIA \\ ${ }^{2}$ Faculty of Sport Science and Coaching \\ Sultan Idris Education University Malaysia, Tanjung Malim, 35900, MALAYSIA \\ *Corresponding Author
}

DOI: https://doi.org/10.30880/ojtp.2020.05.01.001

Received $10^{\text {th }}$ December 2019; Accepted $28^{\text {th }}$ February 2020; Available online $31^{\text {th }}$ March 2020

\begin{abstract}
Supports on increased academic achievement, in particular, is not provided to student-athletes who enrol undergraduate programs in Malaysia public universities. Almost 40 percent of student- athletes who underwent sessions of study at the undergraduate experience some problems in improving their academic achievement than student's undergraduates who do not engage in sports activities actively. Problems, in order to improve academic achievement among student-athletes, are due to factors of environment that do not support the improvement of academic achievement studentathletes during their study sessions. As a result, student-athletes could not be maintained in the session of study, scholarship, and the implications from the result are they are not allowed to participate in training and also competition. Therefore, the purpose of this study was to identify elements of support enhance academic achievement to student-athletes in aspects of the environment. Qualitative research approach involves 12 respondents representing academia, management institutions and the management of student-athletes to explore elements of support enhance academic achievement in aspects of the environment for student-athletes. A total of 12 experts representing academia, management institutions and the management of student-athletes were selected to analyze the fuzziness consensus of experts. All collected data were analyzed using the fuzzy Delphi method. The result of the analysis found that there are 9 elements in aspects of the environment that fulfil the requirement consensus of experts, which threshold value is equal and less than 0.2 , the percentage of the expert group is more than $75 \%$. Therefore, 9 elements of support to help undergraduate student-athletes at public universities to improve their academic achievement.
\end{abstract}

Keywords: Academic Enhancement Support, Student- Athlete, Environment, Public Universities, Fuzzy Delphi Method

\section{Introduction}

Students are the main asset of each institution of higher education in which students academic achievements plays an important role in producing high-quality graduates to transfer on the social and economic growth of the country forward. It is important for the administration and lectures in higher education institutions to focus on the academic achievement of student- athlete because it will increase on employability among student-athletes. Academic achievement is one of the factors that highly considered by employers in recruitment, especially for fresh graduates. Academic achievements of students are assessed with a cumulative grade point average (CGPA) which is it shows the average grades of all examinations for all semesters in the University (Alfan \& Othman, 2005; Ali, Jusoff, Ali, Mokhtar \& Salamat, 
2009).Unlike ordinary students in Higher Education Institution, student-athletes are the small part of the student population at each educational institution with roles within the campus, have patterns of life and the different needs in their study sessions (Shelangoski, Hambrick, Gross, \& Weber, 2014). As such, most student- athletes earn low academic grades and average score due to the amount of time mostly assigned to give commitments to physical exercise, where at the same time as a student where they have the responsibility to meet the requirements of academic (attending lectures, complete assignments, pass exams) during the study session (Carodine, Almond, \& Gratto, 2001).

\section{Literature Review}

Most of the Higher Education Institution aims to produce students who earn good academic achievement but poor academic performance among student-athletes Allen (1997) and too dependent on other individuals from particular support in order to increase motivation for enhanced achievements in the academic and community environment cause on effect on their participation and achievement in academic (Sack, 1988; Yusof, Chuan, \& Shah, 2013). Adler \& Adler (1985) argues that most student-athletes setting in higher education institutions do not provide and nurture interest towards the development of academic achievement. They just enrolled into study sessions at the university or college to cultivate their careers in sports. They achieved a CGPA of low dropout rate, the higher education level and the low percentage of study. According to Beamon \& Bell (2006); Miller \& Kerr (2002) and Tudor (2014) have the opinion that, the student-athletes at the university achieve lower academic standards compared to students who do not involve in active sports. The result of the findings by Yusof, Chuan, \& Shah (2013) found that the university administration and the role of coach didn't help in developing student-athletes' academic performance in Higher Learning Institution in Malaysia.

A study conducted by Feldpausch (2013) found that there was a problem in the academic performance of student-athletes for individuals involved in sports that are more popular which was because of the lack of academic support from the institutions. In addition, the influence of parents, socioeconomic status and family support structure affect academic achievement student-athletes. Based on Fortes, Rodrigues and Tchantchane (2011) however mentioned there are any findings of the effects of socio-economic status of parents of students' academic achievement. As such, it is important for education institutions' role in providing financial support to the student-athletes, which could help enhance their motivation to improve academic achievement (Yelk, 2013).

Student-athletes are individuals who are experiencing stress in discharging its duties as an athlete and a student in an institution of learning (Yelk, 2013). Student-athletes are including those active individuals in sporting activities who serve as full-time students at educational institutions (Diersen, 2005). By such, the student-athletes involved actively at the university level or the international level should be given special attention and support as they need to cope with various forms of challenges and requirements during sessions of study (Broughton \& Neyer, 2001; Carodine, 2001). Student-athletes in Higher Education Institution have to learn how to balance their responsibilities in terms of sports and also academic in ensuring balanced academic achievements such as the needs of the institution complied. As such, they should streamline the number of hours in the following sports training activities to ensure that they stay fit and at the same time committed to the academic regulations set by the institution. According to Diersen (2005), sport in colleges and universities of the United States is hoped to be a part of student life, which sports could be given the same priority as academic needs for students to be able to involve in outdoor activities and to ensure that students can train their physical ability after undergoing routine and daily academic load.

Without a clear understanding of the issues that can affect academic achievement of student-athletes, the sports administration and the Student Affairs was unable to formulate and provide services in support of student-athletes education sessions in education institutions in ensuring success in academia as a whole. However, predicting academic achievement student- athletes is a challenge because this individual session study the same as ordinary students but have the burden of commitment and academics and sports at the same time.

\section{Methodology}

Fuzzy Delphi Technique was used to explore the support element in environment aspect to help student-athletes at public universities to enhance their academic achievement which a set of questionnaire was developed by the researchers based on findings from the expert interviews. The interviews were conducted with 12 experts specialized in the field of studentathletes. In the second phase, a total of 12 experts were selected to answer the questionnaire. According to Jones and Twist (1978), the number of respondents for the Delphi technique is usually from 10 to 50, therefore, 12 experts were sufficient for this research. Each selected expert has more than 5 years working experiences with student-athletes in public universities. The elements of environment aspects were identified by obtaining the consensus from the participating experts. Table 1 shows the simple Fuzzy Delphi procedures used in determining the elements of environment aspects. 
Table 1 - Fuzzy Delphi Technique

\begin{tabular}{lcc}
\hline Phase & No of Expert & Instrument Design \\
\hline One & 12 & Semi- structured Interview Survey \\
Two & 12 & Questionnaire
\end{tabular}

\subsection{Fuzzy Delphi Technique}

According to Mohd Jamil, Siraj, Hussin, Mat Nor, \& Sapar (2014), the Fuzzy Delphi procedures are composed of six basic steps as follows:

\section{Step 1: Determination of Expert}

A total of 11 experts were involved in answering the questionnaires. The experts were chosen based on their working experiences at least 5 years in the related field of expertise.

\section{Step 2: Linguistic Scale Selection}

In this research, the linguistic scale comprised five-point scale, ranging from (1) strongly disagree, (2) disagree, (3) moderately agree, (4) agree, (5) strongly agree. The triangular fuzzy numbers (TFNs) are more proper to utilize as compare to the crisp numbers in the sense that it can represent the information more rigid in the real situation (Mohd Jamil, Siraj, Hussin, Mat Nor, and Sapar, 2014). Table 2 shows the linguistic five-point scale:

Table 2 - Five-Point Linguistic Scale

\begin{tabular}{lllll} 
& \multicolumn{2}{c}{ Five-Point Linguistic Scale } \\
\cline { 2 - 5 } & \multicolumn{2}{c}{ Linguistic Variable } & \multicolumn{2}{c}{ Fuzzy Scale } \\
\hline $\mathbf{1}$ & Strongly Disagree & 0.0 & 0.0 & 0.2 \\
$\mathbf{2}$ & Disagree & 0.0 & 0.2 & 0.4 \\
$\mathbf{3}$ & Moderately Agree & 0.2 & 0.4 & 0.6 \\
$\mathbf{4}$ & Agree & 0.4 & 0.6 & 0.8 \\
$\mathbf{5}$ & Strongly Agree & 0.6 & 0.8 & 1.0 \\
\hline
\end{tabular}

\section{Step 3: Calculate the Average Value}

The average value was calculated based on the total of linguistic scale number of each item and then divided by the number of experts.

\section{Step 4: Determine the Threshold Value (d)}

If the value of threshold $(d)$ is equivalent to or smaller than 0.2 , it indicates that the consensus and agreement from all experts are achieved. When threshold value is larger than 0.2 , second round of data collection has to be conducted in order to fulfil the requirement for Fuzzy Delphi.

\section{Step 5: Consensus of Expert}

In this stage, the percentages of consensus of each item and overall item have to be determined. If the consensus of experts is equal to or more than $75 \%$, it indicates that the group has reached an agreement. The procedures have to be repeated to ensure the participating group has come to agreement provided the consensus percentage is less than $75 \%$.

\section{Step 6: Defuzzification Process}

The main function of defuzzification process is to determine the ranking and score of item by using one of the three formulas as follows:
i. $A \max =1 / 3 *(\mathrm{~m} 1+\mathrm{m} 2+\mathrm{m} 3)$
ii. $A \max =1 / 4 *(\mathrm{~m} 1+\mathrm{m} 2+\mathrm{m} 3)$
iii. $A \max =1 / 6 *(m 1+m 2+m 3)$ 
For the case of this research, the researchers have chosen formula (i) to obtain the defuzzified values as well as to determine the ranking and score according to the consensus of experts.

\section{Data Analysis and Discussion}

The analysis outputs is based on the consensus from the participating experts indicated that there were nine support elements of environment aspects important for student-athletes at public universities to enhance their academic achievement. The nine support elements were financial support, family support, peer support, institution, faculty, management of student-athlete, sport science services and welfare are state in Table 3.

Table 3 - Data Analysis

\begin{tabular}{|c|c|c|c|c|c|}
\hline \multirow[b]{2}{*}{ Element } & \multirow[b]{2}{*}{ Item } & \multicolumn{2}{|c|}{ Score Value } & \multirow{2}{*}{$\begin{array}{l}\text { Threshold Value, } \\
\text { d }\end{array}$} & \multirow{2}{*}{$\begin{array}{l}\text { Consensus of } \\
\text { Expert }(\%)\end{array}$} \\
\hline & & $\begin{array}{c}\text { Fuzzy } \\
\text { Evaluation }\end{array}$ & $\begin{array}{c}\text { Average Of } \\
\text { Fuzzy Number }\end{array}$ & & \\
\hline \multirow[t]{3}{*}{ Financial Support } & 1 & 9.00 & 0.75 & & \\
\hline & 2 & 8.60 & 0.72 & & \\
\hline & 3 & 8.40 & 0.70 & & \\
\hline \multirow[t]{3}{*}{ Peer Support } & 4 & 8.60 & 0.72 & & \\
\hline & 5 & 8.20 & 0.68 & & \\
\hline & 6 & 7.40 & 0.62 & & \\
\hline \multirow[t]{3}{*}{ Family Support } & 7 & 8.80 & 0.73 & & \\
\hline & 8 & 8.40 & 0.70 & & \\
\hline & 9 & 7.20 & 0.60 & & \\
\hline \multirow[t]{8}{*}{ Institution } & 10 & 8.60 & 0.72 & & \\
\hline & 11 & 8.40 & 0.70 & & \\
\hline & 12 & 8.20 & 0.68 & & \\
\hline & 13 & 8.20 & 0.68 & & \\
\hline & 14 & 7.80 & 0.65 & & \\
\hline & 15 & 7.80 & 0.65 & & \\
\hline & 16 & 8.60 & 0.72 & & \\
\hline & 17 & 8.20 & 0.68 & & \\
\hline \multirow[t]{6}{*}{ Faculty } & 18 & 8.60 & 0.72 & & \\
\hline & 19 & 8.00 & 0.67 & & \\
\hline & 20 & 8.80 & 0.73 & 0.0125 & $88 \%$ \\
\hline & 21 & 9.00 & 0.75 & & \\
\hline & 22 & 9.20 & 0.77 & & \\
\hline & 23 & 9.00 & 0.75 & & \\
\hline \multirow{10}{*}{$\begin{array}{l}\text { Management of } \\
\text { Student-Athlete }\end{array}$} & 24 & 8.00 & 0.67 & & \\
\hline & 25 & 7.20 & 0.72 & & \\
\hline & 26 & 7.40 & 0.62 & & \\
\hline & 27 & 9.00 & 0.75 & & \\
\hline & 28 & 8.60 & 0.72 & & \\
\hline & 29 & 7.80 & 0.65 & & \\
\hline & 30 & 7.20 & 0.72 & & \\
\hline & 31 & 8.60 & 0.72 & & \\
\hline & 32 & 8.60 & 0.72 & & \\
\hline & 33 & 8.60 & 0.72 & & \\
\hline \multirow{6}{*}{$\begin{array}{l}\text { Sport Science } \\
\text { Services }\end{array}$} & 34 & 7.20 & 0.72 & & \\
\hline & 35 & 7.40 & 0.62 & & \\
\hline & 36 & 7.40 & 0.62 & & \\
\hline & 37 & 9.20 & 0.77 & & \\
\hline & 38 & 9.00 & 0.75 & & \\
\hline & 39 & 8.00 & 0.67 & & \\
\hline
\end{tabular}




\begin{tabular}{llll} 
& 40 & 9.00 & 0.75 \\
\hline Welfare & 41 & 7.40 & 0.62 \\
& 42 & 8.60 & 0.72 \\
& 43 & 8.80 & 0.73 \\
\hline
\end{tabular}

Specifically, the results of analysis showed that the percentages of consensus for the nine support elements were larger than $75 \%$, which is $88 \%$. These nine support elements were financial support, family support, peer support, institution, and faculty, management of student-athlete, sport science services and welfare. This data consists of the threshold value, overall item percentage, average of response and fuzzy evaluation. The results of the Fuzzy Delphi method analysis yielded consensus values of all sub-elements beyond $75 \%$. The Fuzzy Delphi method sets the terms of the expert agreement taken by the researcher to reach an agreement value of more than $75 \%$ so the consensus group is calculated to reach agreement. According to Chu \& Hwang (2008), if the expert consensus obtained by the researcher reaches less than $75 \%$ then the element must be dropped by the researcher.

\section{Discussion}

As a conclusion, Fuzzy Delphi Technique can be considered as an effective method to determine the constructs of a variable that based on the level of consensus among the experts. Fuzzy Delphi Technique consists of six basic steps, namely, selection of experts, linguistic scale selection, compute thee average value, calculate the threshold value, and determine the consensus of experts and lastly defuzzification process. The most important is the use Fuzzy Delphi Technique may significantly reduce time consumption on the questionnaire and save cost. In the other result aspect, the importance of element supports from environment aspects in providing support in order to enhance academic achievement on student-athlete's public institutions of higher education cannot be denied. Academic achievement become the benchmark to rate of dropout students in Higher Education Institution (Larsen, 2013). This study is important to the top management of university in addressing the problems of academic achievement student-athletes in an institution of higher learning.

\section{Acknowledgement}

We are thankful to research assistant, respondents and all quarters who have contributed to the research.

\section{References}

Alder, P., \& Alder, P. (1985). From Idealism To Pragmatic Detachment:the Academic Performance of College Athletes. Sociology of Education, 58(4), 241-250. [Journal]

Alfan, E., \& Othman, N. (2005). Undergraduate students' performance: the case of University of Malaya. Quality Assurance in Education, 13(4), 329-343. [Journal]

Ali, N., Jusoff, K., Ali, S., Mokhtar, N., \& Salamat, A. S. A. (2009). The Factors Influencing Students' Performance at Universiti Teknologi MARA Kedah, Malaysia. Management Science and Engineering, 3(4), 81-90. [Journal]

Allen, M. (1997). The academic socialization of intercollegiate athletes. Unpublished Doctoral Dissertation, University of Connecticut. [Dissertation]

Beamon, K., \& Bell, P. A. (2006). Academics versus athletics: An examination of the effects of background and socialization on African American male student athletes. The Social Science Journal, 43(3), 393-403. [Journal]

Broughton, E. and Neyer, M. (2001), Advising and Counseling Student Athletes. New Directions for Student Services, 2001: 47-53 [Journal]

Carodine, K. (2001). College student athlete success both in and out of the classroom. New Directions for Student [Journal]

Chu, H.-C., \& Hwang, G.-J. (2008). A Delphi-based approach to developing expert systems with the cooperation of multiple experts. Expert Systems with Applications, 34(4), 2826-2840. [Journal]

Diersen, B. A. (2005). Student-Athlete or Athlete Student. [Dissertation]

Feldpausch, B. M. (2013). An Investigation Of Need For Academic Support Programs For Collegiate Athletes. Journal of Chemical Information and Modeling, 53, 1689-1699. [Journal] 
Fortes, P. C., Rodrigues, G., \& Tchantchane, A. (2011). Investigation of Academic and Athletic Motivation on Academic Performance Among University Students, 2, 181-185. [Journal]

Jones, H, and Twiss, B.L (1978). Forecasting technology for planning decision. New York: Macmillan. [Book].

Mohd Jamil, M.R., Siraj, S., Hussin, Z., Mat Noh, N., Sapar, A. (2014). Pengenalan Asas Keadah Fuzzy Delphi Dalam Penyelidikan Rekabentuk Pembangunan. Minda Intelek Agency, Bangi Selangor [Book]

Sack, A. (1988). College sport and the student athlete. Journal of Sport and Social Issues. [Journal]

Shelangoski, B. L., Hambrick, M. E., Gross, J. P., \& Weber, J. D. (2014). Exploring the Role of Educational Institutions in Student-Athlete Community Engagement, 17-42. [Journal]

Yelk, T. (2013). Non-cognitive factors affecting student athlete academic performance. [Dissertation]

Yusof, A., Chuan, C. C., \& Shah, P. M. (2013). Academic Achievement and Sports Involvement of Malaysian University Athletes. Procedia - Social and Behavioral Sciences, 106, 273-281. [Journal] 